\title{
MAPEAMENTO LIDAR NAS FALÉSIAS COSTEIRAS DO LESTE CEARENSE (NORDESTE DO BRASIL)
}

\author{
LIDAR MAPPING IN THE COASTAL CLIFFS OF EAST CEARENSE (NORTHEAST BRAZIL)
}

\author{
Rhaiane RODRIGUES DA SILVA ${ }^{\mathbf{1}}$, Lidriana de Souza PINHEIRO ${ }^{1}$, Antônio Rodrigues \\ XIMENES NETO ${ }^{2}$, Jáder Onofre de MORAIS ${ }^{2}$ \\ ${ }^{1}$ Universidade Federal do Ceará. Instituto de Ciências do Mar (LABOMAR). Avenida da Abolição, 3207 - Meireles, Fortaleza - CE. \\ E-mail: rhaianerodrigues09@gmail.com; lidriana.lgco@gmail.com; antonio.lgco@gmail.com \\ ${ }^{2}$ Universidade Estadual do Ceará. Laboratório de Geologia e Geomorfologia Costeira e Oceânica (LGCO) Avenida Doutor Silas \\ Munguba, 1700 - Itaperi, Fortaleza - CE, E-mail: antonio.lgco@gmail.com; jader.morais@uece.br

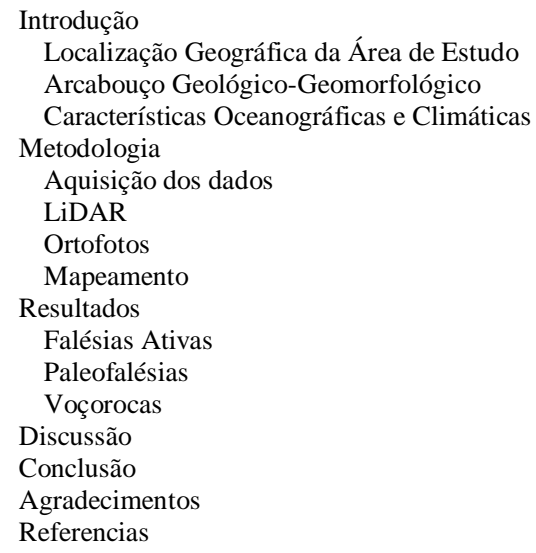

\begin{abstract}
RESUMO - As falésias costeiras representam cerca de $80 \%$ da linha de costa mundial e se classificam de acordo com a influência marinha em sua base em duas categorias: ativas e inativas. No estado do Ceará, Nordeste do Brasil, as falésias situam-se em maior proporção no litoral leste. Com isso, o objetivo do estudo foi de mapear e quantificar as falésias ativas e inativas da zona costeira costa leste cearense focando na litologia, geologia e geomorfologia de topo e das escarpas, através de imagens de alta resolução de LiDAR (Light Detection and Ranging) e Ortofotos. O resultado do estudo mostra que $40 \%$ da linha de costa leste do Ceará são compostas por falésias ativas e/ou inativas, ou seja, $73.83 \mathrm{~km}$ de falésia no litoral, totalizando $36.7 \mathrm{~km}$ de falésias ativas e $39.64 \mathrm{~km}$ de falésias inativas. Apresentando feições como voçorocas bem desenvolvidas nas duas classificações de falésias, identificação de uma erosão remontante e patamares escalonados em uma praia com falésias ativas, relacionados à erosão diferenciada subaérea e neotectônica da região.

Palavras-chave: Lidar; Voçorocas; Patamar Escalonado; Erosão Remontante.
\end{abstract}

\begin{abstract}
Coastal cliffs represent about $80 \%$ of the world's coastline and are classified according to marine influence on their basis into two categories: active and inactive. In the state of Ceará, Northeast Brazil, the cliffs are located in greater proportion on the east coast. The objective of the study was to map and quantify the active and inactive cliffs of the east coast of Ceará, focusing on the top and escarptic lithology, geology and geomorphology through high resolution images of LiDAR (Light Detection and Ranging) and orthophotos. The study results show that $40 \%$ of the east coast of Ceará is composed of active and /or paleocliffs, that is, $73.83 \mathrm{~km}$ of coastal cliffs, totaling $36.7 \mathrm{~km}$ of active cliffs and $39.64 \mathrm{~km}$ of paleocliffs. Featuring features such as well-developed gullies in the two cliff classifications, identification of a remounting erosion and stepped surface on a beach with active cliffs, related to the the erosional retreat and neotectonic.
\end{abstract}

Keywords: LiDAR; Gullies; Stepped Surface; Erosional Retreat.

\section{INTRODUÇÃO}

A zona costeira é composta por feições arenosas e arenítica fortemente cimentadas de diversas morfologias. As falésias são uma feição escarpada (Sunamura, 1992) presente em aproximadamente $80 \%$ da linha de costa mundial (Trenhaile, 1987), e composição associada a rochas sedimentares, ígneas e metamórficas (Bird, 2008), de constituição arenítica fortemente cimentada, sedimentar, calcária e de gelo.

As falésias estão classificadas em dois grupos de acordo com a influência marinha atuante em sua base, são elas as falésias ativas ou falésia costeira (Earlie et al., 2015; Galili \& Zviely, 2019), e falésias inativas ou paleofalésias. As ativas possuem influência marinha na sua morfologia, formando escarpas erodidas pela ação marinha na base (Leite et al., 2016) e modelando seu perfil através da interação de outros agentes marinhos e subaéreos (Moore et al., 2010; Marrero et al., 2018). A evidência de 
uma escarpa inativa com uma linha de costa emergente em frente a ela parece ser uma evidência conclusiva de uma falésia "fóssil" ou "morta" (Guilcher, 1958).

Neste artigo, fazemos a distinção entre (1) falésias inativas e (2) paleofalésias seguindo a denominação feita por Miccadei et al. (2019) que caracteriza a (1) Falésia inativa em uma escarpa vertical variando de $15 \mathrm{~m}$ a $25 \mathrm{~m}$ de altura, possuindo uma barreira que restringe temporariamente os efeitos da erosão marinha, como depósitos de rocha na base ou barreiras antrópicas. As (2) paleofalésias estão entre $15 \mathrm{~m}$ a $50 \mathrm{~m}$ de altura, descritas como falésias que possuem uma distância de centenas de metros para a linha de costa atual restringindo permanentemente os efeitos da erosão marinha. Com isso, vamos utilizar o termo paleofalésias para denominar as falésias que não possuem erosão marinha atuante em sua base. As paleofalésias podem se formar no interior do continente (Domènech et al., 2018), por depressões (Finzi \& Harlev, 2016;) ou por flutuação do nível do mar (Bal, 1997; Ealey \& James, 2001).

As falésias no Brasil ocorrem ao longo do litoral e se estendem desde a região amazônica, por toda região costeira norte e nordeste, até o Sudeste no Rio de Janeiro (Nunes et al., 2011), feições que estão associadas principalmente ao Grupo Barreiras de idade Miocênica (Lima, 2008; Maia, 2012).

O compilado de trabalhos designam o termo "Barreiras" em Série, Grupo ou Formação. Porém os termos "Série" e "Formação" são impróprios, em virtude do desconhecimento dos limites da sua sedimentação no tempo geológico. O termo "Grupo Barreiras" é usado para designar a litoestratigrafia, pois o termo "Grupo", se trata de um conjunto de duas ou mais formações (Suguio, 1998).

Uma área das falésias arenosas atualmente está inserida em Unidades de Conservação (UC's). As falésias do município de Beberibe constituem o Monumento Natural das Falésias com uma área de 31.29 hectares e protegida pelo Decreto $n^{\circ} 27.461$ de 04/06/2004.

Este monumento representa uma unidade de conservação de proteção integral e uso restrito a visitação e contemplação paisagística. Outras unidades de conservação das falésias do litoral leste são a Área de Proteção Ambiental de Canoa Quebrada (Aracati) e a Área de Proteção
Ambiental da Praia de Ponta Grossa (Icapuí), porém por estar dentro da categoria de uso sustentável, a efetiva proteção contra impactos ambientais é branda.

Devido à ocupação crescente em zonas costeiras, a especulação imobiliária, o crescimento do geoturismo que utiliza estas feições geológicas como atrativos principais e maior representatividade no litoral leste do Estado, este estudo propôs mapear e quantificar todas as falésias ativas e inativas da zona costeira leste cearense, através de imagens de alta resolução de LiDAR (Light Detection And Ranging) e Ortofotos, focando na geologia e geomorfologia de topo e das escarpas.

Os estudos de alta resolução que utilizam LiDAR em falésias abrangem o mapeamento e identificação geomorfológica de voçorocas (Godin et al., 2019), levantamento e classificação de entalhes marinhos (Terefenko et al., 2018) monitoramento e análise (Kunh \& Prüfer, 2014; Miccadei et al., 2019; Terefenko et al., 2019) e cálculo de taxas de erosão (Rosser et al., 2015; Esposito et al., 2018; Mushkin et al., 2019).

\section{Localização Geográfica da Área de Estudo}

O estado do Ceará, situado no nordeste do Brasil, está localizado entre as latitudes $2^{\circ} \mathrm{S}$ e $7^{\circ} \mathrm{S}$ e longitudes $37^{\circ} \mathrm{W}$ and $41^{\circ} \mathrm{W}$, possuindo uma linha de costa de $573 \mathrm{~km}$ (IPECE, 2013), destes $184.21 \mathrm{~km}$ estão situados no litoral Leste. A área é morfologicamente diversa, incluindo ambientes de estuário, falésias costeiras, paleofalésias, campos de dunas, praias arenosas e lagoas costeiras. O estudo de mapeamento das falésias está localizado em toda a zona costeira entre o município de Fortaleza (capital do estado) e o estado do Rio Grande do Norte como limite leste (Figura 1). Os municípios que estão presentes nesta área e fazem limite com o mar são Aquiraz, Cascavel, Beberibe, Fortim, Aracati e Icapuí.

\section{Arcabouço Geológico-Geomorfológico}

A análise estratigráfica integrada relaciona a origem do Grupo Barreiras com a elevação eustática global que teve seu máximo na parte média do Mioceno, mais precisamente no intervalo do Burdigralliano ao Serravaliano (12$20 \mathrm{Ma}$ ) (Arai, 2006).

A sedimentação do Barreiras lato sensu sofreu uma interrupção no Tortoniano (início do Mioceno), quando houve um rebaixamento global eustático que ocasionou um extenso evento erosivo nas áreas emersas e a formação de 
cunhas fortemente progradante na porção submersa das bacias submersas. Com a retomada da subida eustática no Plioceno (Zancleano, 4-5
Ma), depositou-se o segundo ciclo, que o autor chama de Barreiras Superior, chamado também de Barreiras Indiviso.

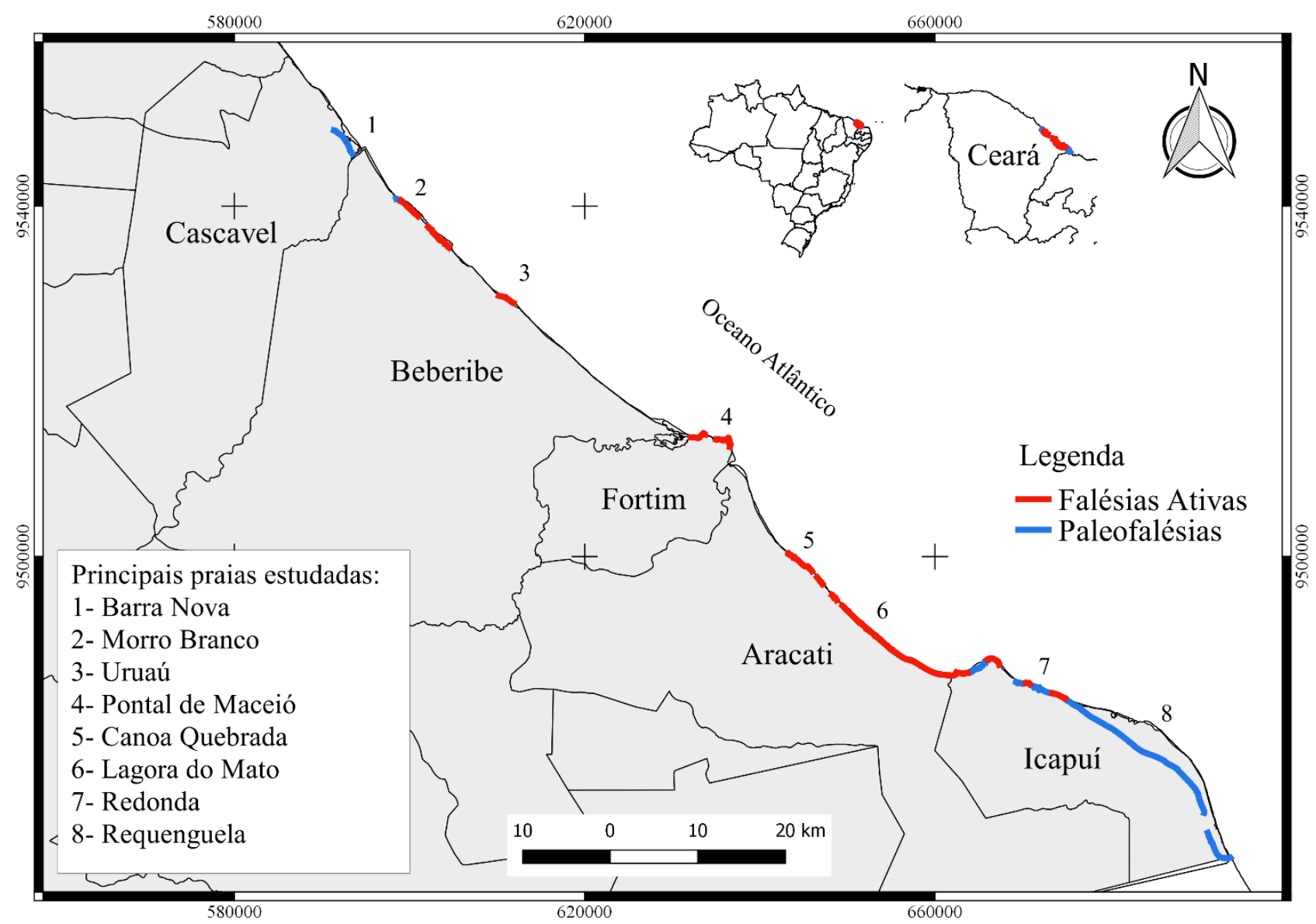

Figura 1 - Mapa de localização da área de estudo, os municípios do litoral leste do Ceará que possuem falésias (Cascavel, Beberibe, Fortim, Aracati e Icapuí), identificando as áreas de falésias ativas, paleofalésias, pontos que possuem voçorocas e as principais praias citadas no estudo.

O Grupo Barreiras no Ceará é composto por três Formações de acordo com o Serviço Geológico Brasileiro (CPRM, 2003), em Formação Camocim, Formação Faceira e Formação Barreiras Indiviso. Os sedimentos desta última Formação foram depositados após a Formação Barreiras (de origem Miocênica), e são chamados de Depósitos Pós-Barreiras (Rossetti et al, 2011a; Rossetti et al, 2013, Souza, 2016). Eles consistem em uma unidade geológica de transição, de maneira discordante da Formação Barreiras, e às vezes são caracterizados como conglomerados de sedimentos com areia e argila intercaladas, semiconsolidados, friáveis e afossilíferos ou principalmente areia (Cohen et al., 2008; Tatumi et al., 2008). Essa classificação de Depósitos Pós-Barreiras é que se assemelha as falésias da costa leste cearense mapeada no estudo, por isso será adotado o termo PósBarreiras para designar as falésias do estudo.

A costa do Ceará é composta por tabuleiros pré-litorâneos que são constituídos predominantemente por sedimentos TércioQuaternários do Grupo Barreiras (Morais et al., 2018), constituído por depósitos de origem terrestre (Bigarella, 1975) areno-argilosos de coloração avermelhada, alaranjada e esbranquiçada, sendo seu sistema de deposicional do tipo leque fluvial (CasteloBranco, 2003). As paleofalésias são compostas pela Formação Barreiras Indiviso e as ativas são compostas pelas, Formação Barreiras, Formação Tibau e Formação Barreiras Indiviso, com afloramentos de plataformas de abrasão na antepraia (Morais et al., 2018). No ponto entre as duas Formações (Tibau e Indiviso) há a presença de fontes d'água na escarpa das falésias em duas praias no município de Beberibe (Morro Branco e Praia das Fontes). A composição da Formação Tibau é um arenito esverdeado, contendo bolas de argila e estruturas de bioturbação deposicionado por sistema fluvial que aflora nos 
municípios de Beberibe e Fortim (Castelo Branco, 2003).

No município de Icapuí a litologia aflorante é composta pelos conjuntos: (i) unidade de rochas carbonáticas, correlacionada à Formação Jandaíra, que ocorre de forma restrita como plataforma de abrasão nas falésias com idade estimada entre 80 a 90 milhões de anos; (ii) unidades de rochas siliciclásticas, correlacionadas às Formação Barreiras e Formação Tibau, que predominam lateral e verticalmente ao longo das falésias; (iii) rochas da Formação Potengi, no topo das falésias (Sousa et al, 2008).

Além disso, um fator importante na formação e geomorfologia das falésias é a tectônica atuante na área (Sousa, 2002; Sousa et al., 2015; Sousa et al., 2018).

\section{Características Oceanográficas e Climáticas}

O clima é predominantemente do tipo Tropical Semiárido Brando marcado por dois períodos definidos - um seco, longo e outro úmido, curto e irregular, (Campos \& Studart, 2003) causado pela migração da Zona de Convergência Intertropical (ZCIT). A distribuição temporal das precipitações é irregular com concentração do total precipitado no primeiro semestre do ano. Cerca de $60 \%$ do total anual precipita-se em apenas três meses (fevereiro/março/abril ou março/abril/maio). Os autores citados acima observaram que a precipitação anual decresce acentuadamente de Fortaleza (1338 mm) em direção a Icapuí (949.2 $\mathrm{mm})$.

A forçante eólica exerce um papel fundamental no litoral do Nordeste brasileiro haja vista a acumulação de dunas e praias arenosas ao longo da costa do Ceará prolongando-se para leste ao litoral norte do Rio Grande do Norte (até Touros) (Morais et al., 2006).

Nos meses de março e abril, ápices do período chuvosos, predominam ventos de SE $\left(120^{\circ}-150^{\circ}\right)$ ao longo do dia, passando a SSE-S $\left(150^{\circ}-180^{\circ}\right)$ durante a noite, com velocidade média variando de 3 a 9 m/s (Maia, 1998).

As ondas apresentam uma forte componente de $\mathrm{E}$ com direções variando entre os quadrantes E, E-NE e E-SE mantendo uma estreita relação com as direções predominantes dos ventos. No primeiro semestre do ano, a frequência de ondas swell é maior, devido à diminuição da influência dos alísios de SE e o aumento a turbulência no Atlântico Norte (Morais et al., 2006).

\section{METODOLOGIA}

Foram analisados os $184 \mathrm{~km}$ ao longo da linha de costa no leste do Ceará, separadas em cinco municípios que fazem fronteira com o mar (Cascavel, Beberibe, Fortim, Aracati e Icapuí). Para a análise foi combinado (1) a interpretação das imagens Lidar; (2) as Ortofotos de alta resolução espacial e (3) geologia e geomorfologia local. Com a compilação dos dados foram identificadas as áreas com falésias ativas e paleofalésias, feições erosivas e formas do topo e escarpa.

A análise teve como objetivo identificar e mapear escarpas, encostas, áreas planas e formas de escarpa. A pesquisa foi baseada em uma abordagem geomorfológica dos assentamentos rochosos e superficiais e de declive, descritos na literatura nacional e internacional.

\section{Aquisição dos Dados}

As imagens Lidar (Light Detection And Ranging) e as Ortofotos foram adquiridos na Superintendência Estadual de Meio Ambiente do Ceará (SEMACE), relativo à Área $2-472 \mathrm{~km}^{2}$ (litoral leste do Estado, entre os municípios de Cascavel e Icapuí) com escala de 1:10.000. Todos os produtos gerados do aerolevantamento atendem a precisão altimétrico do Padrão de Exatidão Cartográfica (PEC) - Classe A (Decreto Federal $n^{\circ}$ 89.817 de 20 de junho de 1984). Esse levantamento foi fruto do Zoneamento Econômico Ecológico (ZEE) da zona costeira, que tem como objetivo conhecer o estado de ocupação e conservação da Faixa Litorânea e Unidades de Conservação Costeiras do Estado do Ceará.

Além das imagens do Lidar foram adquiridas junto ao mesmo órgão e mesmo projeto, Ortofotos com resolução espacial de 0,35 metros $-472 \mathrm{~km}^{2}$. O Modelo Digital de Terreno (MDT) e o Modelo Digital de Superfície (MDS) foram segmentados em 61 recortes em uma articulação de blocos de 5 $\mathrm{km} \times 5 \mathrm{~km}$ alinhados com as coordenadas UTM, Fuso 24S, DATUM SIRGAS 2000, com resolução espacial de $0,5 \mathrm{~m}$. Os arquivos que compõem o MDT foram gerados nos formatos ASC II e em IMG (SEMACE, 2014).

\section{LiDAR}

O princípio de funcionamento do sistema de perfilamento por varredura aerotransportado a Laser - ALS (Airborne Laser Scanning) ou sistema 
aerotransportado de laser para mapeamento do terreno - ALTM (Airborne Laser Terrain Mapper), também conhecido, como altímetro Laser LIDAR (Light Detection And Ranging), de acordo com SEMACE (2014) está baseado na emissão de multifeixe de Laser no espectro infravermelho em direção à superfície terrestre. $\mathrm{Na}$ superfície, estes feixes são refletidos por obstáculos (construções, vegetação ou o próprio terreno) e captados pelo sensor.

Para cada feixe emitido é registrado o tempo de percurso aeronave - obstáculo - aeronave. A partir do tempo de percurso do laser é possível determinar a distância percorrida utilizando para tal a velocidade da luz.

A posição, orientação e variação da altitude da aeronave são combinadas, então, através de métodos de processamento para produzir uma posição tridimensional na superfície da Terra que foi atingida por cada pulso Laser.

Uma vez processada a combinação dos dados registrados pelo Laser Scanner, pelo Sistema Global de Navegação por Satélite (GNSS) e pelo sistema de referência inercial - IMU (Inercial Measurement Unit) ou INS (Inertial Navigation System) na aeronave.

Este sistema é acoplado ao IMU, que integra e armazenam os dados GNSS de dupla frequência e do INS, referentes à posição e altitude da aeronave (Wehr \& Lohr, 1999).

O sistema de perfilamento a Laser constituiuse, então, na integração de sensores e equipamentos no avião onde os ecos de Laser emitidos em intervalos regulares foram armazenados em um computador de bordo e depois repassados para outro computador de escritório, onde foram analisados e processados.

Com relação ao Perfilamento Laser para a Área 2, o mesmo foi feito a uma velocidade de 80 knots ou $148 \mathrm{~km} / \mathrm{h}$ a uma altura média de $1250 \mathrm{~m}$ ou 4100 pés acima do nível do mar, com a utilização do sensor RIEGL LMS-Q680i com taxa de repetição do pulso de $80 \mathrm{Khz}$ PRR. Velocidade de voo de 68 $\mathrm{m} / \mathrm{s}$ nos dias 08, 10, 22, 23 e 24 de Junho e 04 e 05 de julho de 2014 (SEMACE, 2014).

\section{Ortofotos}

A Ortofoto é a foto corrigida de todas as deformações presentes na fotografia aérea, decorrentes da projeção cônica da fotografia - que dá a foto um aspecto distorcido, como se a imagem tivesse sido arrastada do centro para as bordas da foto - e das variações do relevo, que resultam em variação na escala dos objetos fotografados. A
Ortofoto equivale geometricamente ao mapa de traço, todos os pontos se apresentam na mesma escala, podendo seus elementos ser medidos e vetorizados com precisão. É possível medir distâncias, posições, ângulos e áreas, como num mapa qualquer.

Essa correção segue o princípio da Retificação Diferencial que consiste em transferir tons da fotografia aérea para uma malha regular representando a projeção ortogonal do terreno. Participaram deste processo a calibração da câmera, os parâmetros de orientação das aerofotos, o Modelo Digital do Terreno e pontos de ligação de detalhes homólogos entre fotos. O MDT permitiu a determinação da cota $\mathrm{Z}$ correspondente a cada pixel da Ortofoto digital.

A ortoprojeção foi realizada pelo software especialista TerraPhoto que garante a boa qualidade dos produtos. Nos casos em que uma Ortofoto exigiu composição por mais de uma imagem, foi aplicada a mosaicagem.

Os mosaicos foram cortados em blocos de $5 \mathrm{x}$ $5 \mathrm{~km}$ no formato GEOTIFF/TFW e estão alinhados com as coordenadas UTM, Fuso 24, Hemisfério Sul, DATUM SIRGAS 2000, com resolução espacial de $0,35 \mathrm{~m}$, os quais permitem a sobreposição dos vetores a fim de viabilizar a interpretação de detalhes e pormenores topográficos em escala final de 1:10.000 (SEMACE, 2014).

\section{Mapeamento}

O mapeamento e a vetorização foram realizados nos softwares QGis 2.18 e Global Mapper v.11.00 utilizando as imagens das Ortofotos e de Lidar. Para mapear as falésias foram criados arquivos vetoriais do tipo shapesfiles de linha, marcando a borda das falésias ativas e paleofalésias do litoral Leste. Durante o mapeamento minucioso, foram obser-vadas e detalhadas feições morfológicas como voçorocas, patamares escalonados e erosão remontante na borda das falésias.

Foi feita a quantificação em quilômetros das falésias por município, distância das paleofalésias para a linha de costa atual, morfologia e perfil topográfico da escarpa.

Das voçorocas observadas nas falésias foram destacadas as duas maiores, que estão localizadas em duas praias relevantes para o litoral leste, devido ao alto potencial turístico, crescente urbanização nas últimas décadas e composição geológica facilmente erodida, nas praias de Morro Branco (Beberibe) e Canoa Quebrada (Aracati). 


\section{RESULTADOS}

Foi verificado que $40 \%$ da linha de costa do leste do Ceará são compostas por falésias ativas e/ou paleofalésias (Figura 1), ou seja, $74.33 \mathrm{~km}$ de falésia no litoral, totalizando $36.7 \mathrm{~km}$ de falésias ativas $(19.37 \%)$ e $39.14 \mathrm{~km}$ de falésias paleofalésias (20.70\%) (Tabela 1).

Com destaques para os municípios de Aracati e Icapuí, por apresentarem as maiores linhas contínuas de falésias ativas $(18.45 \mathrm{~km})$ e paleofalésias $(33.64 \mathrm{~km})$. Os municípios que apresentam falésias ativas, com ação marinha atuante na erosão da escarpa, são Fortim (4.37 $\mathrm{km})$, Icapuí $(6.11 \mathrm{~km})$, Beberibe $(7.74 \mathrm{~km})$ e Aracati $(18.45 \mathrm{~km})$. Os que apresentam paleofalésias, ou seja, quando a ação marinha não atua na escarpa (apenas processos subaéreos), são Beberibe $(1.7 \mathrm{~km})$, Cascavel $(3.8 \mathrm{~km}) \mathrm{e}$ Icapuí (33.64 km) (Tabela 1, Figura 1).

Tabela 1 - Mapeamento, características morfológicas e litológicas das cinco áreas pesquisadas nas falésias costeiras. Identificando Ac como Falésias ativas e Pc como Paleofalésias.

\begin{tabular}{|c|c|c|c|c|c|}
\hline & Cascavel & Beberibe & Fortim & Aracati & Icapuí \\
\hline \multicolumn{6}{|c|}{ MAPEAMENTO } \\
\hline Falésias Ativa & - & Sim & Sim & Sim & Sim \\
\hline Paleofalésias & Sim & Sim & - & - & Sim \\
\hline Falésias ativa (km) & - & 7.74 & 4.44 & 18.45 & 6.11 \\
\hline Paleofalésias $(\mathbf{k m})$ & 3.8 & 1.6 & - & - & 33.64 \\
\hline Distância máxima para a linha de costa & $1391 \mathrm{~m}$ & $166.8 \mathrm{~m}$ & - & - & $3270 \mathrm{~m}$ \\
\hline Distância média para a linha de costa & $1186 \mathrm{~m}$ & $74.95 \mathrm{~m}$ & - & - & $745 \mathrm{~m}$ \\
\hline Voçorocas & 168 & $\begin{array}{c}\text { Ac: } 534 \\
\text { Pc: } 28\end{array}$ & 38 & 1178 & $\begin{array}{l}\text { Ac: } 247 \\
\text { Pc: } 237\end{array}$ \\
\hline \multicolumn{6}{|c|}{ FEIÇÕES MORFOLÓGICAS } \\
\hline Altura média & $21.13 \mathrm{~m}$ & $\begin{array}{l}\text { Ac: } 16.31 \mathrm{~m} \\
\text { Pc: } 14.62 \mathrm{~m}\end{array}$ & $5.9 \mathrm{~m}$ & $19.75 \mathrm{~m}$ & $\begin{array}{l}\text { Ac: } 32.48 \mathrm{~m} \\
\text { Pc: } 33.09 \mathrm{~m}\end{array}$ \\
\hline Altura máxima & $27.63 \mathrm{~m}$ & $\begin{array}{l}\text { Ac: } 24.86 \mathrm{~m} \\
\text { Pc: } 15.73 \mathrm{~m}\end{array}$ & $7.88 \mathrm{~m}$ & $29.54 \mathrm{~m}$ & $\begin{array}{l}\text { Ac: } 42.6 \mathrm{~m} \\
\text { Pc: } 46.82 \mathrm{~m}\end{array}$ \\
\hline Declividade máxima & $70.54^{\circ}$ & $\begin{array}{c}\text { Ac: } 78.55^{\circ} \\
\text { Pc: } 64^{\circ}\end{array}$ & $73.13^{\circ}$ & $76^{\circ}$ & $\begin{array}{l}\text { Ac: } 78.37^{\circ} \\
\text { Pc: } 70.54^{\circ}\end{array}$ \\
\hline Declividade média do perfil & $27.72^{\circ}$ & Ac: $42.54^{\circ} \mathrm{Pc}: 30.45^{\circ}$ & $32^{\circ}$ & $31.63^{\circ}$ & $\begin{array}{l}\text { Ac: } 43.21^{\circ} \\
\text { Pc: } 34.39^{\circ}\end{array}$ \\
\hline Patamar escalonado & - & - & - & - & Sim \\
\hline
\end{tabular}

\section{Falésias Ativas}

A linha de falésias ativas se inicia no município de Beberibe, especificamente na praia de Morro Branco e Uruaú somando 7.74 $\mathrm{km}$ de extensão. Seguindo para o leste, elas ressurgem no município de Fortim, na praia de Pontal do Maceió, apresentando falésias de duas composições litoestratigráficas (Arenosa do Pós-Barreiras e arenítica fortemente cimentada da Formação Tibau), somando 4.44 km de extensão.

No litoral de Aracati são apresentadas a maior linha de falésias ativas contínua do Ceará, totalizando $18.45 \mathrm{~km}$, ocupando $50.32 \%$ do litoral do município.

Essa linha de falésias ativas segue até o município de Icapuí por mais $6.11 \mathrm{~km}$, e então essas falésias seguem caminho para dentro do continente tornando-se paleofalésias, que voltam a ser falésias ativas passando a fronteira do estado, no litoral do Rio Grande do Norte (Figura $1)$.

Estas, são falésias, em sua maioria, de composição friável areno-argilosas originadas dos depósitos Pós-Barreiras, facilmente erodidas por ações marinhas e climática, com presença de ravinamentos e voçorocamentos em toda sua extensão (Figura 2).

A altura máxima encontrada do pacote sedimentar das falésias ativas é de $42.6 \mathrm{~m}$, e a altura média varia entre $5.9 \mathrm{~m}$ e $32.48 \mathrm{~m}$ (Tabela 1). No município de Icapuí encontramos as maiores elevações em falésias ativas, na praia de Ponta Grossa a altura máxima da escarpa das falésias alcançou 42.6 metros.

As outras falésias ativas apresentam altura máxima de $29.54 \mathrm{~m}$ (Aracati), $24.86 \mathrm{~m}$ (Beberibe) e, por último, as falésias mais baixas estão no município de Fortim, com 7.88 m (Tabela 1). 


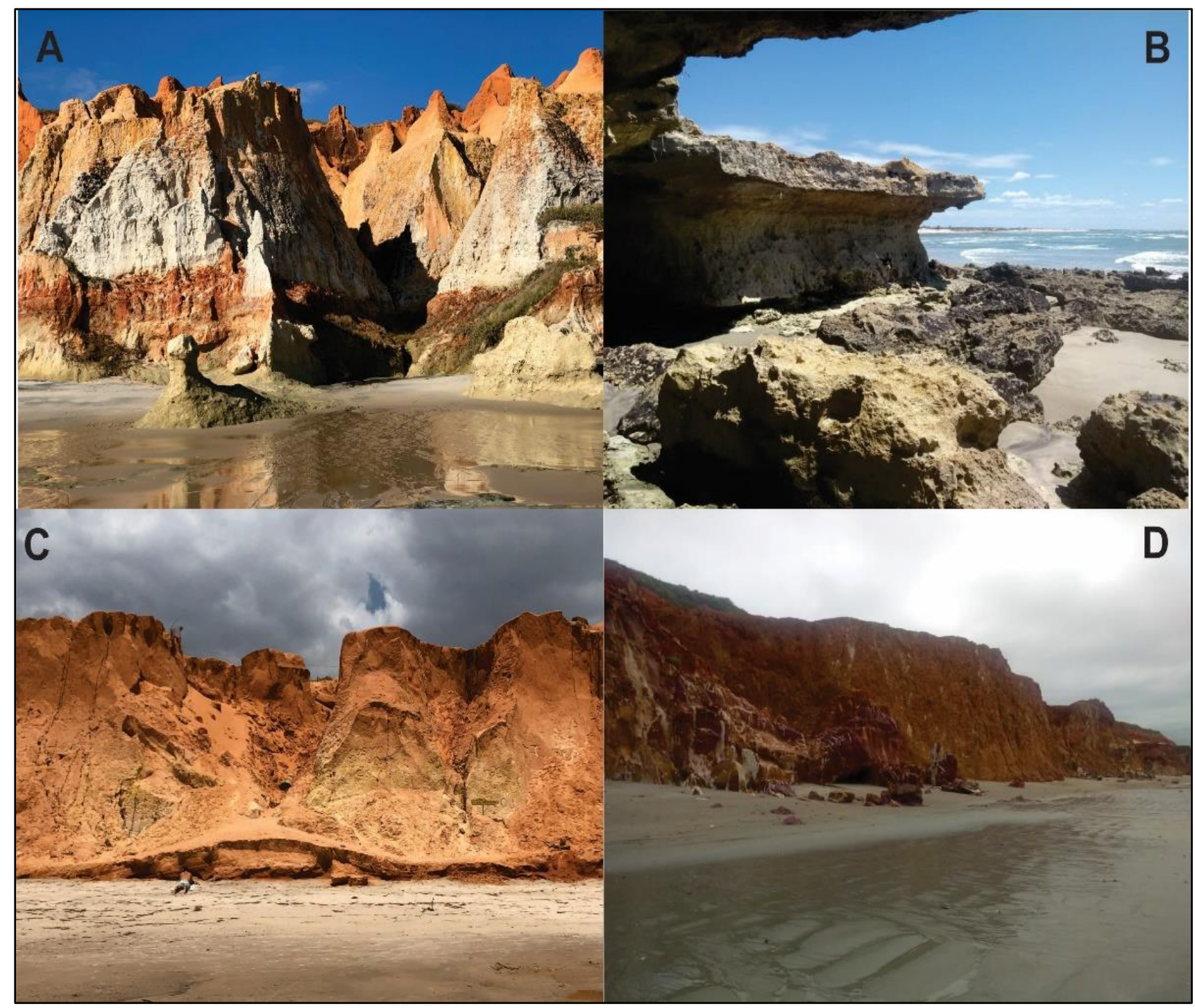

Figura 2 - Falésias ativas do litoral leste do Ceará nas praias de A- Morro Branco (Beberibe); B- Pontal de Maceió (Fortim); C- Canoa Quebrada (Aracati) e D- Ponta Grossa (Icapuí).

Então temos as falésias ativas mais baixas na porção oeste e a elevação vai subindo, em torno de $30 \mathrm{~m}$, até alcançar as falésias mais altas na porção leste.

Em relação à declividade, os perfis das falésias ativas apresentam uma máxima variando entre $78.55^{\circ}$ e $73.13^{\circ}$. Em relação a declividade média do perfil os valores variando entre $31.63^{\circ}$ e $42.54^{\circ}$, devido a cicatrizes de desmoronamentos pretéritos que suavizam a região basal da escarpa. As elevações máximas foram de $78.55^{\circ} \mathrm{em}$ Beberibe, $78.37^{\circ} \mathrm{em}$ Icapuí, $76^{\circ}$ em Aracati e $73.13^{\circ}$ em Fortim.

As feições morfológicas formadas nas falésias ativas e observadas pelo mapeamento do Lidar são voçorocas bem desenvolvidas, solapamentos na base das falésias e os patamares escalonados.

Estes ocorrem apenas no município de Icapuí, em uma extensão de $2.82 \mathrm{~km}$ de linha de costa, podendo ser observado na praia de Redonda. As escarpas deste patamar alcançam altura máxima de 46.82 metros e inclinação máxima de $74.82^{\circ}$ (Figura 3).

Os patamares das falésias ativas na praia de Redonda (Icapuí) possuem diferentes litologias, no qual a superior é mais friável e erosiva dos depósitos Pós-Barreiras, e a inferior é um conglomerado firme da Formação Barreiras.

A camada superior está a uma altura média de $30.15 \mathrm{~m}$ e o patamar inferior à altura média de $15.84 \mathrm{~m}$, a distância entre as duas camadas varia de $44.39 \mathrm{~m}$ e de $5.74 \mathrm{~m}$.

A distância da crista superior para a linha de costa varia de $25.2 \mathrm{~m}$ a $156.59 \mathrm{~m}$, a declividade da camada superior varia de $65.51^{\circ}$ e $35.89^{\circ}$, com média de $53.59^{\circ}$, a camada inferior possui declividade da escarpa variando entre $77.54^{\circ} \mathrm{e}$ 72. $89^{\circ}$. 

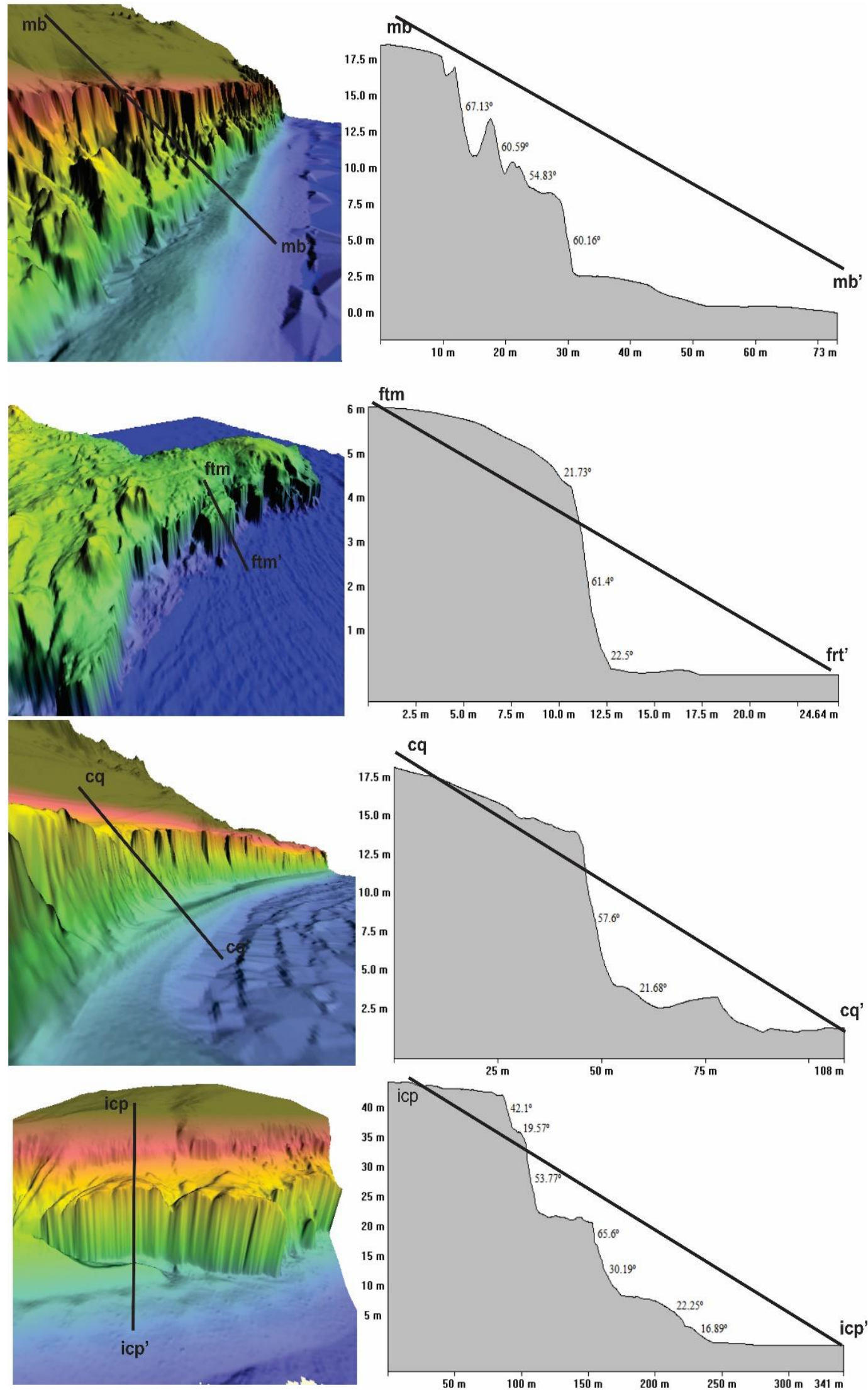

Figura 3 - Perfis topográficos das falésias ativas (unidades de medida em metros e em graus) nos municípios de Beberibe (mb), Fortim (ftm), Aracati (cq) e Icapuí (icp), indicando o início e final do perfil topográfico de cada praia.

Por apresentarem duas camadas sedimentares distintas, a erosão subaérea ocorre de forma distinta, no qual na camada superior é comprovada com a existência de 231 voçorocas e 49 no inferior, estas possuem forma pequenas, com ravinas bem desenvolvidas, perpendiculares a linha de costa, e paralelas entre si. E na camada inferior é possível observar solapamentos na base 
das falésias, indicando uma área de risco a desmoronamentos e quedas de blocos.

\section{Paleofalésias}

As paleofalésias encontram-se em três municípios do litoral leste do Ceará, e são as maiores linhas de falésia do Estado com 39.04 $\mathrm{km}$ de extensão, no qual a maioria dessas falésias estão situadas no município de Icapuí, totalizando $33.64 \mathrm{~km}$ de linha de paleofalésias. Seguindo para oeste temos o município de Beberibe com $1.7 \mathrm{~km}$ de paleofalésias em duas praias (Morro Branco e Uruaú), e por último o município de Cascavel com $3.8 \mathrm{~km}$ de extensão. A distância máxima das paleofalésias para a linha de costa varia entre $166.8 \mathrm{~m}$ em Beberibe e 3270 m em Icapuí com presenta de terraços marinhos indicando as antigas cristas praiais, até a linha de costa atual.

A distância máxima no município de Cascavel é de $1391 \mathrm{~m}$, isso indica as variações do nível do mar em alguns pontos na costa leste cearense (Figura 4).

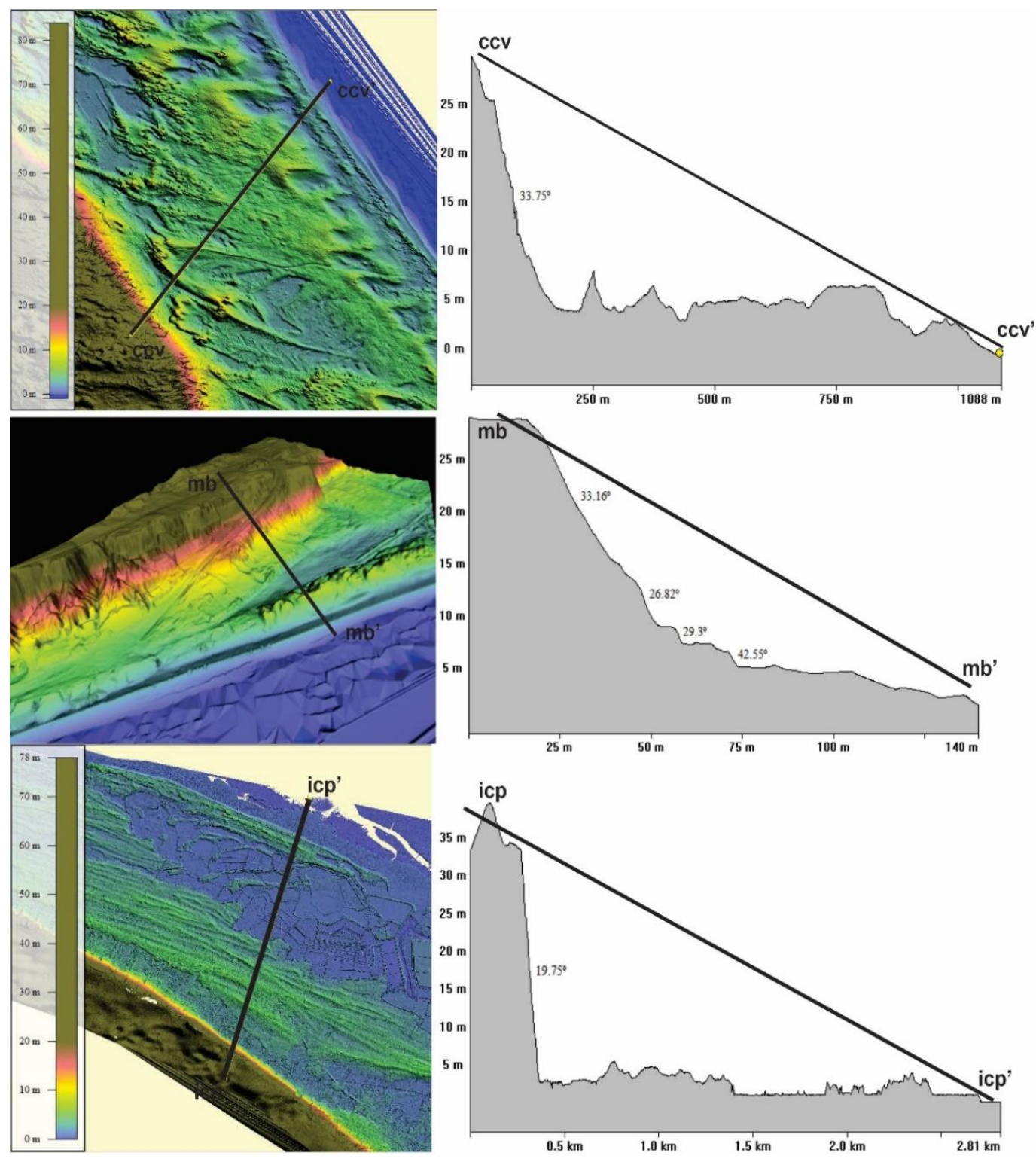

Figura 4 - Perfis topográficos nas paleofalésias no litoral leste do Ceará, nos municípios de Cascavel (ccv), Beberibe (mb) e Icapuí (icp), utilizando imagens do Lidar e indicando o início e final do perfil topográfico. Detalhando a escarpa das falésias inativas que estão a distâncias de um quilometro da linha de costa e imagens in loco dos locais.

As paleofalésias no município de Icapuí possuem vegetação no topo em quase toda sua extensão, assim elas puderam ser mapeadas devido à sobreposição dos dados de alta resolução do LiDAR. Com isso, a elevação máxima da escarpa é de 46.82 metros e a média é de $33.09 \mathrm{~m}$.

Apesar de possuir grande elevação, o perfil dessas paleofalésias é intermediário, com declividade máxima de $58.52^{\circ}$ e declividade média de $47.14^{\circ}$ (Figura 4).

A segunda maior linha de paleofalésias está 
no município de Cascavel, na praia de Barra Nova, e possui extensão de $3.8 \mathrm{~km}$. A altura máxima da escarpa dessas paleofalésias é de 27.63 metros e média de $21.13 \mathrm{~m}$, estando a uma distância média de $1288 \mathrm{~m}$ da linha de costa atual (Figura 4).

Além disso, a declividade máxima em um ponto da escarpa pode chegar a $70.54^{\circ}$ e a declividade média de $33.75^{\circ}$, indicando a suavização do perfil desde a sua inatividade, com alto índice de erosão subaérea somando 168 voçorocas na linha de paleofalésias.

As falésias de Barra Nova possuem a mesma litologia das paleofalésias nas praias de Morro Branco e do patamar superior das falésias de Icapuí, em relação às falésias ativas, possuem a mesma litologia das ativas em Aracati e das arenosas do Fortim.

Por último, a linha de paleofalésias no município de Beberibe possui a menor extensão com $1.5 \mathrm{~km}$ e localizada em duas praias, são elas Morro Branco e Uruaú. A altura máxima das escarpas é de $15.73 \mathrm{~m}$ e a altura média é de 14.64 m (Figura 4).

Em relação à declividade, a máxima alcança $64^{\circ}$ e a média $56.04^{\circ}$ e a distância delas para a linha de costa alcança uma máxima de $166 \mathrm{~m}$ e possui média de $74.95 \mathrm{~m}$, apresentando dunas em processo de fixação entre as paleofalésias e a linha de costa. Assim como as falésias da ativas da região, seu perfil é erodido diferencialmente, pois seu topo é altamente friável, sedimentos do
Grupo Barreiras e sua escarpa e boa parte do topo é protegido por vegetação

\section{Voçorocas}

Voçoroca é a remoção do solo por canais através da acumulação de escoamento superficial, são geralmente definidos pela sua profundidade de canal que pode variar de 0.5 a $30 \mathrm{~m}$ (Soil Science Society of America, 2001).

Essa feição morfológica é comum nas falésias do Ceará, devido ao seu caráter friável e arenoso. Com isso, foram contabilizadas um total de 2430 voçorocas no litoral leste do Ceará, sendo 1997 em falésias ativas e 433 em paleofalésias.

Das falésias ativas, o município de Aracati possui cerca de $60 \%$ do total de voçorocas (1187 voçorocas), entre elas a praia de Canoa Quebrada se destaca por apresentar a segunda maior voçoroca das falésias do Ceará.

Esta possui formato retilíneo com extensão de 123 metros e largura máxima do canal de $6.12 \mathrm{~m}$, com largura média de $3.9 \mathrm{~m}$ e declividade de $9^{\circ}$, permitindo o fácil acesso de moradores e turistas com baixa mobilidade alcançar a faixa de praia (Figura 5).

A área da voçoroca é de $2.67 \mathrm{~km}^{2}$ em um perímetro de 368 metros, com isso, o volume de sedimentos transportados desta voçoroca para a zona costeira é de $162.28390 \mathrm{~m}^{3}$, e o volume de sedimentos restantes na área é de $349.35993 \mathrm{~m}^{3}$. Apesar de possuir um canal largo, essa voçoroca apresenta apenas 8 ravinas e sucos pouco desenvolvidos (Figura 5A).

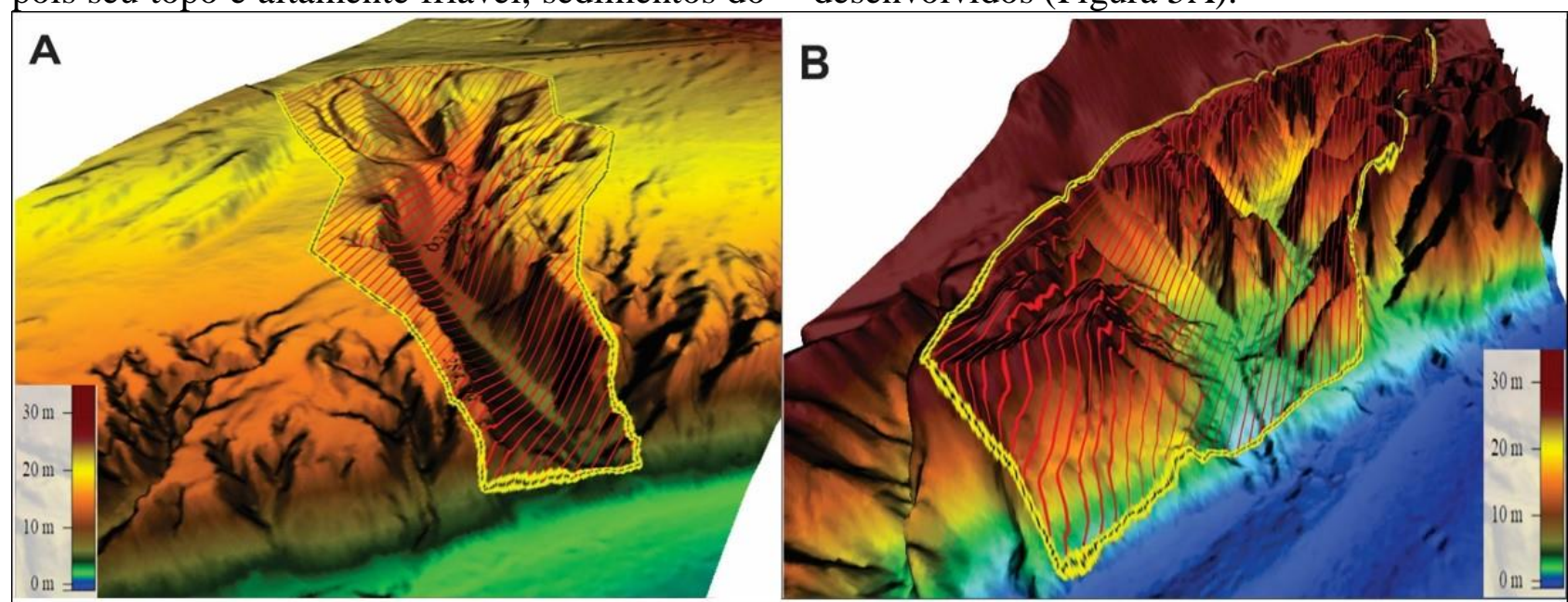

Figura 5 - Área das voçorocas em imagem Lidar nas praias de A- Canoa Quebrada (Aracati) e B- Morro Branco (Beberibe).

A declividade das paredes do canal é distinta, com a margem direita possuindo uma escarpa com declividade máxima de $73.2^{\circ}$ e sedimentos inconsolidados acumulando na base da parede do canal com declividade média de $36.54^{\circ}$. A margem esquerda é muito escarpada com declividade máxima de $71^{\circ}$ e não possui sedimentos inconsolidados em sua base, além disso, apresenta resquícios erosão eólica em sua escarpa, que deixa a falésia com aspecto de ruínas.

A maior voçoroca em falésias ativas, que se 
destaca no litoral leste do Estado, está localizada na praia de Morro branco (Beberibe), pois possui a maior voçoroca do litoral leste do Ceará, com área de $10.5 \mathrm{~km}^{2} \mathrm{e}$ perímetro de $536 \mathrm{~m}$, com isso o volume de sedimentos removidos dessa voçoroca é de $886.953 \mathrm{~m}^{3}$ e o volume restante de sedimentos desta área é de $2295.620 \mathrm{~m}^{3}$.

A extensão do canal é de 201 metros e a largura máxima alcança $14.37 \mathrm{~m}$, com largura média de $8.63 \mathrm{~m}$. Sua morfologia é rica de reentrâncias, com um formato parecido como uma bacia hidrográfica (Figura 5B), permitindo criar trilhas por dentro do canal da voçoroca e um parque para atividades turísticas.

Nesta também é possível verificar a declividade de sua escarpa máxima de $71^{\circ} \mathrm{e}$ média de $43.38^{\circ}$. Seu canal é mais suave, possuindo uma declividade média de $6.39^{\circ}$.

Outra morfologia composta por áreas de voçorocas perpendiculares a linha de costa bem definidas, com o topo erodido verticalmente destacando o ravinamento remontante, de coloração sedimentar da camada superior branco e inferior alaranjada localizado na praia de Lagoa do Mato (Aracati). Essa erosão está presente em $4.46 \mathrm{~km}$ da linha de falésias ativas do município, composta por um topo recuado e voçorocas em formato parecido com o de uma bacia hidrográfica, ou raízes ramificada, em média de 103 metros de comprimento e canal largo com média de $19.31 \mathrm{~m}$ de largura, declividade da escarpa dessas falésias varia de $18.62^{\circ}$ na base a $51.34^{\circ}$ na área mais escarpada.

\section{DISCUSSÕES}

A localização das falésias (ativas e paleofalésias) também foi mapeado por Morais et al, (2018), porém sem a quantificação destas no litoral e sem as feições morfológicas derivadas destas falésias. Ximenes Neto et al., (2019) mapearam as paleofalésias no Ceará, identificando 15 linhas de paleofalésias, sendo 5 delas no litoral leste, totalizando 89,7 km dos 573 $\mathrm{km}$ de linha de costa do Estado, sendo o litoral entre Fortaleza-Icapuí com (32,4 km), 6.64 km a menos do que as paleofalésias que foram mapeadas no estudo. Os dois trabalhos não identificaram as paleofalésias do litoral de Uruaú (Beberibe).

As falésias são associadas à fatores eustáticos e/ou tectônicos (Bird, 2008), no qual as ativas podem apresentar plataformas de abrasão na faixa praial adjacente às falésias, as paleofalésias apresentam longas distâncias para a linha de costa atual com várias cristas praiais neste percurso. As plataformas de abrasão são formadas no processo de recuo das falésias e ficam dispostas na faixa praial, abaixo da linha de preamar, alguns alinhamentos rochosos descontínuos que compõem plataformas de abrasão e/ou rochas de praia (beach rocks). Elas indicam um nível do mar mais baixo que o atual, no qual foi ocorrendo o recuo da falésia e deixando uma plataforma exposta conectada diretamente com a litologia dos materiais mais resistentes, com é o caso da Formação Tibau, presente na área basal das falésias ativas de Beberibe e Fortim, e da Formação Jandaíra em Icapuí. O material da Formação Tibau no litoral leste do Ceará é constituído por arenitos com matriz silto-arenosa de cores cinzentas e cimento calcífero (Morais et al., 2006) presentes nos municípios de Beberibe (praias de Morro Branco e Praia das Fontes), Fortim (praia de Pontal de Maceió), Aracati e Icapuí. Vale ressaltar que a Formação Tibau e a Formação Jandaíra estão dentro do Grupo Apodi juntamente com a Formação Açu, que afloram na região litorânea emersa na forma de falésias e pontais rochosos que interagem com os processos hidrodinâmicos na elaboração da zona costeira (Lima et al., 2000).

O perfil das falésias ativas é modelado constantemente por ações marinhas em sua base e fatores climáticos no topo, com ações sazonais de solapamento, que é a retirada de sedimentos da base, e desmoronamento, que é o desprendimento dos sedimentos superiores. Essas ações suavizam ou escarpam o perfil destas, e segundo Davidson-Arnott (2010), falésias que possuem escarpas até $40^{\circ}$ são chamadas de bluffs e escarpas com inclinação $>40^{\circ}$ são chamas de cliffs. Com isso, a escarpa das falésias ativas está classificada como cliffs, e no setor mais basal onde encontra-se cicatrizes de desmoronamento o perfil é suavizando classificando como Bluff. As paleofalésias estão dentro da classificação de bluffs devido a maior erosão aérea e subaérea, presença de vegetação. Essa classificação pode ser atrelada ao fato que cliffs por serem mais íngremes em falésias ativas apresentam maiores riscos e vulnerabilidade a desmorona- 
mentos e quedas e blocos. As bluffs possuem um perfil mais estável, não apresen-tando riscos causados por erosão marinha, assim, as bluffs podem ter evoluído a partir de uma cliff.
As paleofalésias do município de Beberibe possuem pouca extensão e escarpas características de falésias ativas, isso porque são possivelmente as paleofalésias mais recentes (Figura 6).

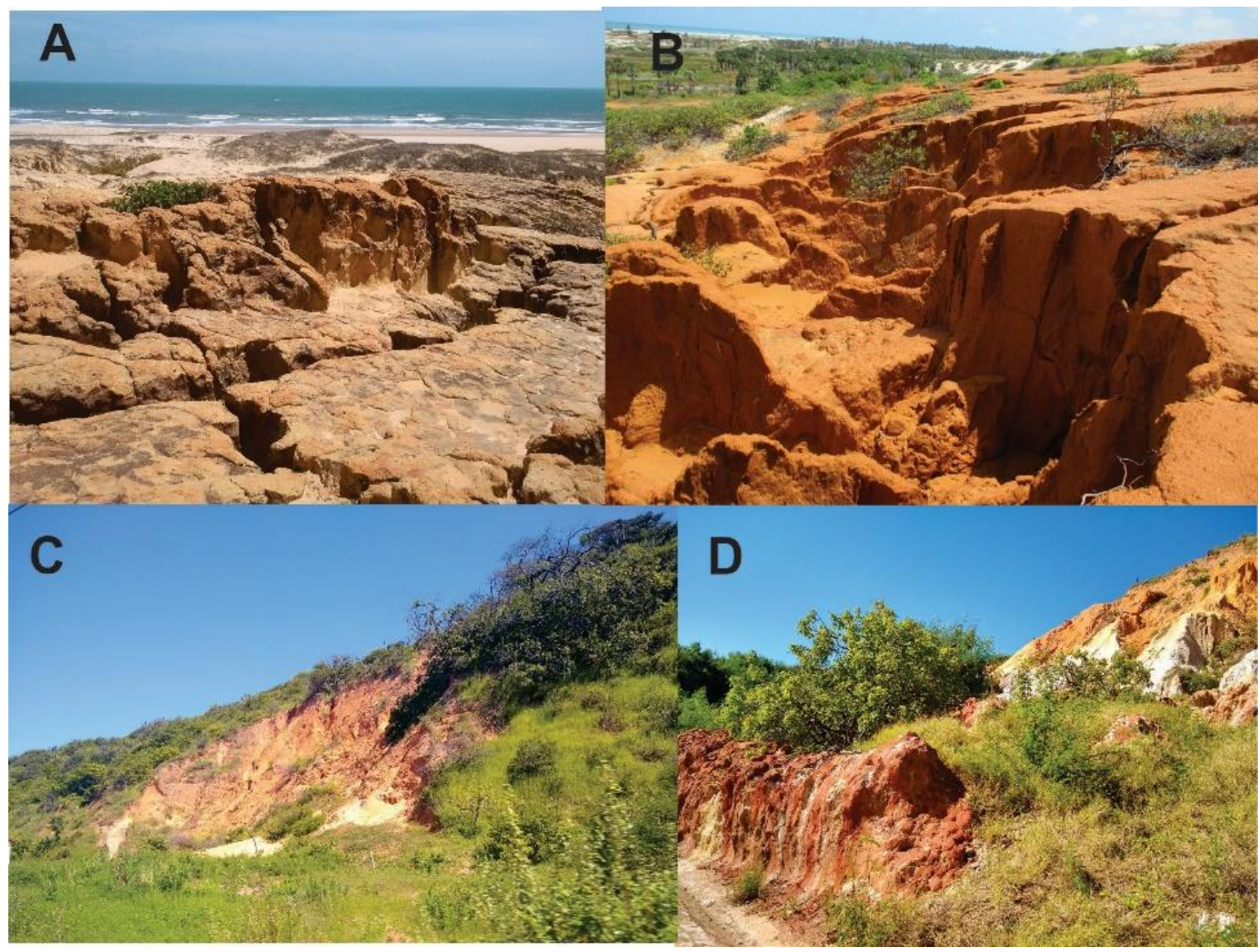

Figura 6 - Imagens das paleofalésias no litoral leste do Ceará, nas praias de A- Uruaú (Beberibe); B- Barra Nova (cascavel); C- na região de Requenguela (Icapuî), onde estão as falésias mais distantes da linha de costa; D - Redonda (Icapuí).

As paleofalésias do litoral leste possuem declividade de escarpas em torno de $40^{\circ}$, caracterizadas como bluffs. Além disso, estas falésias estão diretamente relacionadas com a variação do nível do mar durante o Quaternário, pois são antigas linhas de costas que estão em um nível mais do que o nível do mar atual, podendo ser utilizadas como marcadores de flutuação (Suguio, 1985; Ealey and James, 2001; Bird, 2008). Na costa do Ceará, Morais (1998) associa a presença de paleofalésias aos máximos transgressivos do Sangamoniano ( 125.000 anos A.P) e Holoceno Médio ( 5.000 anos A.P). Posteriormente a estes níveis altos, o nível do mar regrediu e formou terraços marinhos, evidenciados em cristas praiais progradante.

Seguindo em relação ao perfil das falésias, Emery e Kuhn (1980) afirmam que quanto maior o grau de inclinação da escarpa da falésia maior é a ação marinha comparada com a ação subaérea, e quando o perfil está suavizado isso indica erosão subaérea é atuante ou maior que a marinha, comprovando isso nas paleofalésias de Icapuí que possuem inclinação da escarpa compatível com bluffs. A vegetação em falésias costeiras sedimentares está relacionada à estabilização de taludes, ocorrendo principalmente no topo das falésias por vegetação arbustiva de pequeno porte e rasteira, que protegem contra a perda sedimentar e minimiza o escoamento superficial. Nas falésias inativas de Icapuí apresenta vegetação mais desenvolvida com porte arbustivo, indicando um período em que a erosão subaérea ocorreu por um período maior, comparado as paleofalésias de Beberibe.

A erosão de falésias ativas por ações marinhas e climáticas é descrita em um estudo global chamado de GlobR2C2 (Premaillon et al. 2018), com 1530 falésias estudadas e mais de 1680 taxas de erosão estimadas, afirmando que a taxa de erosão média para rochas fortes é de $2.9 \mathrm{~cm} / \mathrm{ano}$, para rochas médias de $10 \mathrm{~cm} /$ ano e rochas fracas de $23 \mathrm{~cm} /$ ano. De acordo com sua litologia descrita por Silva (2017), Morais et al., (2018), 
as falésias mapeadas do litoral leste do Ceará podem ser consideradas entre médias e fracas. Mushkin et al. (2019) obtiveram resultados um pouco menores em um estudo de taxas de recuo recentes (anual-decadal) versus taxas de recuo antigas (centenário-milenar), variando entre 3 $\mathrm{cm} /$ ano a $9 \mathrm{~cm} / \mathrm{ano}$. Assim, as falésias do litoral leste possuem uma taxa de recuo variando possivelmente entre $9 \mathrm{~cm} /$ ano a $23 \mathrm{~cm} /$ ano.

As falésias ativas do município de Fortim possuem dupla litologia, uma de composição arenítica fortemente cimentada com $3.37 \mathrm{~km}$ de extensão, localizado na praia de Pontal de Maceió, na desembocadura esquerda do rio Jaguaribe. Apresenta baixa altura devido sua constituição fortemente cimentada compacta, representante de um pequeno afloramento da Formação Tibau na região, com presença de solapamentos causado por ação marinha, formando pequenas cavernas. Além disso, apresenta uma plataforma e abrasão na praia adjacente como resquícios de erosão, descrito primeiramente como sendo formado por beach rocks (Smith \& Morais, 1984) e atualmente pesquisadores afirmam que essas falésias foram moldadas em sedimentos arenosos fortemente cimentados da Formação Tibau (Leite et al., 2016) em função do arqueamento crustal decorrente da ação dos sistemas de falhas presentes no Graben Jacaúna (Castelo Branco, 2003).

Além dessa composição arenítica fortemente cimentada, podemos observar nas imagens ortofotos $1.07 \mathrm{~km}$ de falésias arenosas friáveis, classificadas dentro do Grupo Barreiras como
Depósitos Pós-Barreiras, assim como as falésias dos municípios de Beberibe, Aracati e Icapuí, formada por forçante fluvial. Carvalho Neta (2007) identificou paleofalésias na costa de Fortim, situado na margem esquerda do Rio Jaguaribe, porém estas se apresentam como pequenos afloramentos, espaçados, de poucos metros de altura, não sendo perceptível no mapeamento. Além disso, as falésias regidas por forçantes fluviais não entraram no mapeamento, somente as falésias que possuem ou não influência marinha.

A altura das falésias ativas na praia de Icapuí apresentaram os maiores valores, mesmo assim está bem abaixo dos 70 metros indicado por Meireles (2014) na região, e menos que a metade das falésias no litoral da Califórnia, na costa oeste dos Estados Unidos, possuem falésias arenosas ativas que podem alcançar até 100 metros de altura (Sterrett, 2002). Apesar desse valor para as falésias de Icapuí, no litoral do Rio Grande do Norte (estado vizinho a leste) as falésias na região da Serra do Mel alcançam 200 m (Maia \& Bezerra, 2014). Indicando que as falésias vão aumentando de altitude no sentindo oeste - leste, possivelmente por influências tectônicas da região (Sousa, 2002; Souza et al., 2008).

Os patamares escalonados na costa de Icapuí (Figura 7), de acordo com Meireles (2014), são vinculados aos processos erosivos diferenciados devido às diferenças sedimentológicas. A fácies arenosa superior é mais suscetível à erosão subaérea pluvial e a camada abaixo, mais resistente é mais escarpada devido ao ataque direto das ondas.

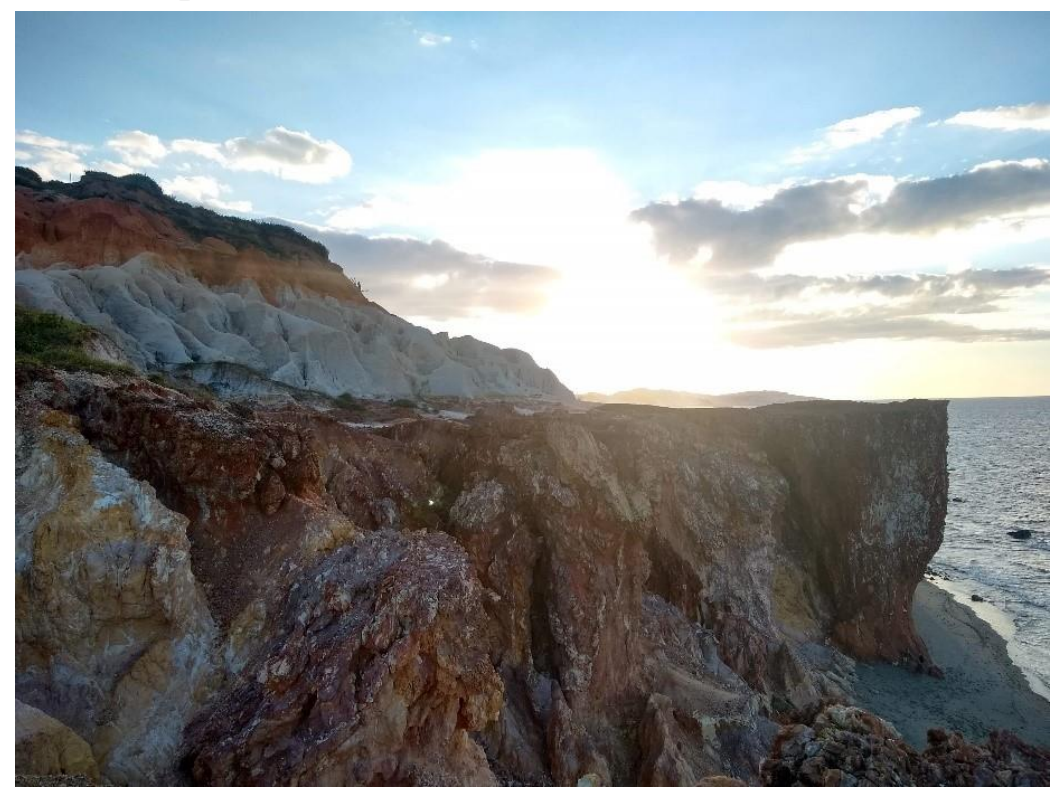

Figura 7 - Patamar escalonado na praia de Redonda (Icapuí), mostrando a erosão diferenciada das camadas superior e inferior, as voçorocas no topo da camada superior de perfil mais suavizado e solapamento na base da falésia ativa da camada inferior de perfil mais escarpado. 
Essas características refletem diferenças na suscetibilidade à erosão entre camadas, truncam as camadas ou grãos estruturais, ou são uma combinação das duas. O primeiro pode ser atribuído a processos gerais de intemperismo, como aborda Meireles (2014). No entanto, o truncamento (especialmente se horizontal) deve ser atribuído a processos de "corte" mais agressivos, como uma forçante neotectônica da região.

De acordo com estudos de neotectônica e falhas interpretadas por sísmica de reflexão no município de Icapuí (Souza et al., 2008; Maia, 2012), justifica as maiores alturas encontradas em falésias no Ceará neste local, e os patamares escalonados distantes em torno de $44 \mathrm{~m}$ entre os patamares e $156 \mathrm{~m}$ da linha de costa. Não excluindo a erosão em camadas apresentada por Meireles (2014), mas um compilado das duas.As feições morfológicas presentes nas falésias como voçorocas bem desenvolvidas, erosão remontante e patamar escalonado são desenvolvidas nessa região devido às características litoestratigráficas de sedimentos semiconsolidados, friável, areníticos, fracamente cimentados (Morais et al., 2006). Os processos de voçorocamentos são desencadeados por sistemas inadequados de cultivo e irrigação, sobre pastoreio, trilhas de transporte de madeira, construção de estradas e urbanização (Valentin et al., 2005). Pinheiro et al (2009) realizou num estudo em campo nesta voçoroca e obteve resultados parecidos ao apresentado pelas imagens do Lidar, e afirma que o solo encontrase em estágio avançado de compactação, o que além de contribuir no aumento do escoamento superficial dificulta o processo de recarga do aquífero. A quantidade de voçorocas encontradas em falésias ativas foi maior que as encontradas em paleofalésias, apenas em Icapuí a quantidade é similar entre as classificações das escarpas. Apesar de as paleofalésias serem modeladas majoritariamente por ações subaéreas (chuva, vento, temperatura, escoamento), elas apresentaram baixa quantidade de voçorocas, e estas são pequenas e pouco desenvolvidas. Isso ocorre porque as paleofalésias possuem uma alta cobertura vegetal em seu topo e em sua escarpa, motivo pelo qual imagens de LiDAR são essenciais para o mapeamento de paleofalésias.

A formação e erosão de voçorocas é importante para o aporte e balanço sedimentar das praias no litoral cearense, assim como dunas e estuários, as falésias perdem sedimentos para equilibrar a erosão e progradação da linha de costa. Na costa de Oceanside na Califórnia, Estados Unidos, as voçorocas contribuem com $44.7 \%$ dos sedimentos que chegam à praia (Sterrett, 2002). Na ilha de Santa Cruz também na Califórnia entre $32-78 \%$ de volume de sedimentos erodidos no leque aluvial, em volume o resultado foi de $21.854 \mathrm{~m}^{3}$ de material perdido em uma área de $25.323 \mathrm{~m}^{2}$ ou $0.86 \mathrm{~m}^{3} \mathrm{~m}^{2}$ (Perroy et al. 2010).

A evolução da área das voçorocas em relação à ocupação no topo das falésias de Canoa Quebrada (Aracati) feita por Silva (2017) no período de 2004 a 2016 mostrou uma redução em $11 \%$ sua área de voçorocas, devido ao aumento da ocupação urbana que foi de $85 \%$ no mesmo período, que cresceu no sentido continente-praia e paralelo à linha de costa, em alguns pontos descaracterizando as falésias para construção de casas e barracas de praia. É possível que eventos climáticos esporádicos causem aberturas de voçorocas e grandes percas de volume de sedimento. $\mathrm{Na}$ maior voçoroca de Canoa Quebrada foi formada por um evento climático de alta energia em abril/2009, com chuvas torrenciais em curto período, somado ao escoamento superficial.

$\mathrm{O}$ volume sedimentar que as voçorocas das falésias arenosas transportam para as praias adjacentes é três vezes a 16 vezes maior que o volume de sedimentos que são transportados pelas correntes litorâneas. Segundo o estudo feito por Maia (1998) sobre cálculos para o volume de sedimentos transportados pela corrente de deriva litorânea no litoral de Fortaleza, a partir da Praia do Futuro, determinou que são carreados em média $855.000 \mathrm{~m}^{3} / \mathrm{ano}$ de areias e, pelo cálculo através da batimetria, com um valor muito semelhante, com $881.000 \mathrm{~m}^{3} / \mathrm{ano}$. Deste modo, Maia faz uma média e estima que o volume de sedimentos transportados longitudinalmente pela corrente de deriva litorânea é de aproximadamente $860.000 \mathrm{~m}^{3}$ por ano.

A erosão remontante indica um alto escoamento superficial para as bordas da falésia, evidenciando os riscos subaéreos da região, que apresenta em alguns pontos uma zona urbana próxima a ruptura do relevo. Smith \& Morais (1984) descreveram uma parte das falésias dessa região situadas na praia de Marjolândia, a leste da desembocadura do rio Jaguaribe, como uma falésia bem baixa parcialmente cortada por 
ravinas com todos os depósitos sendo rapidamente erodidos. Confirmando uma área vulnerável às ocupações e com alto índice de mobilidade em toda a costa de falésias do município de Aracati.

As áreas de falésias devem ser rigorosamente preservadas pela sua importância no mecanismo de evolução da faixa costeira bem como de sua vulnerabilidade à ocupação. As falésias ativas nos municípios de Beberibe e Aracati são destaques no litoral leste do Ceará devido ao seu alto potencial turístico e especulação imobiliária, com as praias de Morro Branco e Canoa Quebrada.

O principal problema que se interpõe ao uso e ocupação dessas feições reside em suas condições ecodinâmicas fortemente instáveis e em sua alta vulnerabilidade. Os riscos e vulnerabilidade dessas feições em constante modelagem são descritos por Boruff et al (2005); Morais et. al. (2006); Del Río \& García (2009).

\section{CONCLUSÕES}

As falésias arenosas friáveis e resistentes do Ceará estão associadas principalmente aos Depósitos Pós-Barreiras e Formação Tibau, se concentram no litoral leste indicando o início da Bacia Potiguar. As paleofalésias mapeadas indicam a variação do nível do mar na região em três localidades, como verificado um recuo regresso variável de $1200 \mathrm{~m}$ (Cascavel) a $3200 \mathrm{~m}$ (Icapuí).

Todas as falésias mapeadas (ativas e inativas) demonstram uma erosão subárea atuantes, representado por voçorocas que variam seu tamanho de poucos metros até 201 metros, que estão presentes em todas das falésias que não estão cobertas por vegetação. As duas maiores voçorocas estão em áreas muito urbanizadas com escoamento superficial atuante, porém as duas possuem formas distintas. Enquanto uma na praia de Morro Branco possui voçorocas e ravinas bordejantes, parecido com afluentes de um rio, possui uma forma de escoamento mais natural. A outra, está localizada na praia de Canoa Quebrada é mais larga e retilínea, indicando o ponto final específico no qual o escoamento superficial da urbanização alcança.

Em um total de 73 quilômetros de linha de falésias ativas e inativas, apenas um trecho de três quilômetros possui uma área de proteção ambiental integral atuando, impedindo novas ocupações irregulares na área. Essa região é conhecida como Parque Monumental das Falésias de Morro Branco, gerido por um órgão ambiental federal ICMBio (Instituto Chico Mendes de Conservação da Biodiversidade) em parceria com órgão ambiental estadual (SEMACE - Superintendência Estadual de Meio Ambiente) e órgão ambiental municipal (SEPLAN - Secretaria de Planejamento e Desenvolvimento Urbano e Meio Ambiente). Outras duas unidades de conservação nas falésias são a Área de Proteção Ambiental da Praia de Ponta Grossa e a Área de Proteção Ambiental de Canoa Quebrada. A última incorpora as falésias arenosas, porém sua eficácia não é efetiva, devido ao alto nível de ocupações no topo e na base da falésia e suas características geológicas erosivas da Formação Barreiras Indiviso.

\section{AGRADECIMENTOS}

Agradecemos ao Laboratório de Geologia e Geomorfologia Costeira e Oceânica - LGCO, da Universidade Estadual do Ceará - UECE, pela infraestrutura e apoio do corpo científico para realização das atividades de coleta, processamento e análise dos dados sedimentológicos. E à Coordenação de Aperfeiçoamento de Pessoal de Nível Superior - CAPES, pela concessão das bolsas de doutorado.

\section{REFERÊNCIAS}

ARAI, M. A Grande Elevação Eustática do Mioceno e Sua Influência na Origem do Grupo Barreiras. Revista do Instituto de Geociências - USP, v. 6, n. 2, p. 1-6, 2006.

BAL, A.A. Sea caves, relict shore and rock platforms: evidence for the tectonic stability of Banks Peninsula, New Zealand. Journal of Geology and Geophisics, v. 40, p. 299-305, 1997.

BIGARELLA, J.J. The Barreiras Group in northeastern Brazil. Anais Academia Brasileira de Ciência, v.47, p. 365-393, 1975.

BIRD, E. Coastal geomorphology: an introduction / Eric Bird. — Second. ed. p. 67 - 106. Australia: Wiley, 2008.
BORUFF, B.J.; EMRICH, C.; CUTTER, S.L. Erosion Hazard Vulnerability of US Coastal Counties. Journal of Coastal Research, v. 21 (5), p. 932-942, 2005.

CAMPOS, J.N.B. \& STUDART, T. Climatologia. CAMPOS, A.A. (ed). In: A zona Costeira do Estado do Ceará: Diagnóstico para a Gestão Integrada. Fortaleza: AQUASIS, p. 51-53, 2003

CARVALHO NETA, M.L. Evolução Geomorfológica Atual e Análise Ambiental da Foz do Rio Jaguaribe. Fortaleza, 2007. 126p. Dissertação (Mestrado em Geografia). Universidade Federal do Ceará. 
CASTELO BRANCO, M.P.N. Análise dos Sistemas Deposicionais e Dinâmica Costeira do Município de Aquiraz, Estado do Ceará, com auxílio de Imagens de Sensoriamento Remoto. Brasília, 2003. 250p. Dissertação de Doutorado $\mathrm{N}^{\circ}$ 066. Instituto de Geociência. Universidade de Brasília.

DAVIDSON-ARNOTT, R. Introduction to Coastal Processes and Geomorphology. Cambridge, 442 p. 2010.

DEL RÍO, L. \& GARCIA, F.J. Erosion risk assessment of active coastal cliffs in temperate environments. Geomorphology, v. 112, p. $82-95,2009$.

EALEY, P.J. \& JAMES, H.C.L. Shore platforms and raised beach deposits at Porthleven and the Most Southerly Point, west Cornwall. Geoscience in south-west England, v. 10, p. 205209, 2001.

EARLIE, C.S.; YOUNG, A.P.; MASSELINK, G.; RUSSELL, P.E. Coastal cliff ground motions and response to extreme storm waves, Geophys. Res. Lett., v. 42, p. 847-854, 2015.

EMERY, K.O. \& KUHN. Sea Cliffs: Theirs, Processes, Profiles, And Classification. Geological Society of America Bulletin. v. 93, p. $644-654,1980$.

ESPOSITO, G.; SALVINI, R.; MATANO, F.; SACCHI, M.; TROISE, C. Evaluation of geomorphic changes and retreat rates of a coastal pyroclastic cliff in the Campi Flegrei volcanic district, southern Italy. Journal of Coastal Conservation, v. 22, inssue 5, p. 957-972, 2018.

FINZI, Y. \& HARLEV, N., A regional approach for modeling cliff retreat rate: The Makhteshim Country, Israel. Geomorphology, v. 271, p. 65-73, 2016.

GALILI, E. \& ZVIELY, D. Geo-archaeological markers reveal magnitude and rates of Israeli coastal cliff erosion and retreta. Journal of Coastal Conservation, v. 23, p. 747-758, 2019.

GODIN, E.; OSINSKI, G.R.; HARRISON, T.N.; PONTEFRACT, A.; ZANETTI, M. Geomorphology of Gullies at Thom as Lee Inle t, Devon Island, Canadian High Arctic. Permafrost and Periglac Process, v. 30, p. 19 - 34, 2019.

GUILCHER, A. Coastal and Submarine Morphology. London: Methuen, 274p. 1958.

IPECE- Instituto de Pesquisa e Estratégia Econômica do Ceará. Ceará em números, 2013. Disp. em: <http://www.ipece.ce.gov.br/categoria5/ceará-emnumeros>.

KUNH, D. \& PRÜFER, S. Coastal cliff monitoring and analysis of mass wasting processes with the application of terrestrial laser scanning: A case study of Rügen, Germany. Geomorphology, v. 213, p. 153-165, 2014.

LEITE, N.S.; RIZZATI, I.M.; SILVA, E.V. Análise Paisagística do Litoral do Município de Fortim - Ceará: Subsídios ao Planejamento Ambiental Local. Espaço Aberto, v. 6, n. 2, p. 103-125, 2016.

LIMA, L.C.; MORAIS, J.O.; SOUZA, M.J.N Compartimentação territorial e gestão regional do Ceará. 268p. Editora FUNECE, Fortaleza, 2000.

MAIA, L.P. Processo costeros y balance sedimentario ao lo largo de Fortaleza (NE- Brasil): implicaciones para uma gestión adecuada de la zona litoral. Espanha, 1998. 269 p. Tese (Doutorado), Universidade de Barcelona

MAIA, R.P. Geom orfologia e Neotectônica no Vale do rio Apodi-Mossoró RN. Natal, 2012. 218 p. Tese (Doutorado em Geodinâmica e Geofísica), Centro de Ciências Exatas e da Terra - Universidade Federal do Rio Grande do Norte.

MAIA, R.P. \& BEZERRA F.H.R. Inversão neotectônica do relevo na Bacia Potiguar, nordeste do Brasil. Revista Brasileira de Geomorfologia, v.15, n. 1, p. 61-74, 2014.

MARRERO, S.M.; HEIN, A.S.; NAYLOR, M.; ATTAL, M.; SHANKS, R.; WINTER, C.; WOODWARD, J.; DUNNING, S.; WESTOBY, M; SUGDEN, D. Controls on subaerial erosion rates in Antarctica. Earth and Planetary Science Letters, v. 501, p. 56-66, 2018.

MEIRELES, A.J.A. Geomorfologia costeira: funções ambientais e sociais/Antonio Jeovah de Andrade Meireles Fortaleza: Imprensa Universitária, 2014, 489 p.
MOORE, R.; ROGERS, J.; WOODGET, A. Climate change impact on cliff instability and erosion. FCRM $>10$, International Centre, Telford 28th June - 1st July 2010.

MORAIS, J.O. Processos Interativos na Elaboração da Zona Costeira do Estado do Ceará e Impactos Associados. Fortaleza, Brasil. 1998. 225 p. Tese (Professor Titular), Universidade Estadual do Ceará.

MORAIS, J.O; FREIRE, G.S.; PINHEIRO, L.S.; SOUZA, M.J.N.; CARVALHO, A.M.; PESSOA, P.R.S. Capítulo Ceará. In: Erosão e progradação do litoral brasileiro. MUEHE, D. (Coordr); Ministério do Meio Ambiente (MMA).1ed. Rio de Janeiro, v.1, p. 132-134p, 2006.

MORAIS, J.O.; PINHEIRO, L.S.; PESSOA, P.R.S.; FREIRE, G.S.; CARVALHO, A.M.; GUERRA, R.G.P.; BARROS, E.L.; MOURA, F.J.M. Capítulo Ceará. In: Erosão e progradação do litoral brasileiro. MUEHE, D. (Coordr); Ministério do Meio Ambiente (MMA). 2ed. Rio de Janeiro, v.1, p. 261 - 289, 2018. MUSHKIN, A.; KATZ, O.; PORAT, N. Overestim ation of shortterm coastal cliff retreat rates in the eastern Mediterranean resolved with a sediment budget approach. Earth Surface Processes and Landforms, v. 44, p. 179-190, 2019.

NUNES, F.C.; SILVA, E.F.; VILAS BOAS, G.S. Grupo Barreiras: características, gênese e evidências de neotectonismo. In: Coord., CARVALHO NUNES, F. \& FRAGA DA SILVA, E. Dados eletrônicos. Rio de Janeiro: Embrapa Solos, 2011. 31 p. (Boletim de Pesquisa e Desenvolvimento / Embrapa Solos, ISSN 1678-0892; 194).

PERROY, R.L.; BOOKHAGEN, B.; ASNER, G.P.; CHADWICK, O.A. Comparison of gully erosion estimates using airborne and ground-based LiDAR on Santa Cruz Island, California. Geomorphology, v. 118, p. 288-300, 2010.

PINHEIRO, L.S.; MORAIS, J.O.; MAIA, L.P. Capacidade de carga recreacional das trilhas do Monumento das Falésias de Beberibe-CE. In: 9 TH INTERNTIONAL SYMPOSIUM ON GIS AND COMPUTER CARTOGRAPHY FOR COASTAL ZONE MANAGMENT AND V CONGRESSO SOBRE PLANEJAMENTO E GESTÃO DAS ZONAS COSTEIRAS DOS PAÍSES DE EXPRESSÃO PORTUGUESA, 2009, Itajaí. CoastGIS 2009. Atas...Itajaí: Univali, 2009. v. 1. p. 255-255.

PREMAILLON, M.; REGARD, V.; DEWEZ, T.J.B.; AUDA, Y. GlobR2C2 (Global Recession Rates of Coastal Cliffs): a global relational database to investigate coastal rocky cliff erosion rate variations. Earth Surface Dynam, v. 6, p. 651-668, 2018.

ROSSER, N.J.; PETLEY, D.N.; LIM, M.; DUNNING, S.A.; ALLISON, R.J. Terrestrial laser scanning for monitoring the process of hard rock coastal cliff erosion. Quarterly Journal of Engineering Geology and Hydrogeology, v. 38, p. 363375, 2005.

SEMACE, Superintendência Estadual de Meio ambiente. Relatório Técnico Com Descritivo dos Produtos do Aerolevantamento - Área $02 \quad$ (09/2014) 4413_Rlt_SEMACE_13. 04413_SEMACE: Reestruturação e Atualização do Mapeamento do Projeto Zoneamento Ecológico Econômico Do Ceará - Zona Costeira e Unidades de Conservação Costeiras, 2014.

SMITH, A.J. \& MORAIS, J.O. Estudos preliminares sobre a geologia ambiental costeira do estado do Ceará, Nordeste do Brasil. Arquivo de Ciências do Mar, v. 23, p. 85 - 96, 1984.

SOIL SCIENCE SOCIETY OF AMERICA. Glossary of Soil Science Terms. Soil Science Society of America, Madison, WI. Disp.em: <http://www.soils.org/sssagloss/>. 2001

SOUSA, D.C. Litoestratigrafia e deformação Cenozoica na região de Icapuí, Ceará, e implicações para a estruturação de campos de petróleo na borda ocidental da Bacia Potiguar (NE do Brasil). Natal, 2002. 222 p. Tese (Doutorado em Geodinâmica) - Centro de Ciência Exatas e da Terra, Universidade Federal do Rio Grande do Norte.

SOUSA, D.C.; SÁ, E.F.J.; ANTUNES, A.F. Deformação neógena e suas implicações na estruturação dos campos de petróleo na região de Icapuí-Ponta Grossa (CE), Bacia Potiguar 
emersa. Revista Brasileira de Geociências, v. 38, n. 2, p. 97 110, 2008.

SOUSA, D.C.; SÁ, E.F.J.; VITAL, H.; NASCIMENTO, M.A.L. Falésias na Praia de Ponta Grossa, Icapuí, CE - Importantes deformações tectônicas cenozóicas em rochas sedimentares da Formação Barreiras. Sítios Geológicos e Paleontológicos do Brasil SIGEP 120, 2008. In: WINGE, M.; SCHOBBENHAUS, C.; SOUZA, C.R.G.; FERNANDES, A.C.S.; BERBERTBORN, M.; QUEIROZ, E.T.; (Eds.) Sítios Geológicos e Paleontológicos do Brasil. Publicado na Internet em 24/09/2008 no endereço $<$ http://sigep.cprm.gov.br/sitio120/sitio120.pd.

SOUZA, C.M.P.; COSTA, L.M.; MOREAU, A.M.S.S; GOMES R. L. Sedimentological Parameters and Dating Of PostBarreiras Sediments From Region The Coastline. Mercator, v. 15, n. 3, p. 127-139, 2016.

SOUZA, D.C.; SÁ, E.F.J.; ANTUNES, A.F. Deformação neógena e suas implicações na estruturação dos campos de petróleo na região de Icapuí-Ponta Grossa (CE), Bacia Potiguar emersa. Revista Brasileira de Geociências, v. 38, n. 2, p. 97 110, 2008.

STERRETT, K. California Department of Boating and Waterways and State Coastal Conservancy, 2002. California Beach Restoration Study. Sacramento, California, 2002.

SUGUIO, K.; MARTIN, L.; ABÍLIO, C.S.P. BITTENCOURT, J.M.L. DOMINGUEZ, J.F.; AZEVEDO, A.E.G. Flutuações do nível relativo do mar durante o Quaternário Superior ao longo do litoral brasileiro e suas implicações na sedimentação costeira. Revista Brasileira de Geociências. v. 15, n. 4, p. 273 286, 1985.

SUNAMURA, T. Geomorphology of Rocky Coasts, Wiley,
England, 302 p. 1992.

TEREFENKO, P. PAPROTNY, D.; GIZA, A.; MORALESNÁPOLES, O.; KUBICKI, A.; WALCZAKIEWICZ, S. Monitoring Cliff Erosion with LiDAR Surveys and Bayesian Network-based Data Analysis. Remote Sensing, v. 11, n. 7, p. 843, 2019.

TRENHAILE, A.S. The Geomorphology of Rock Coast. Oxford University Press. 344 p. 1987.

VALENTIN, C.; POESEN, J.; LI, YONG. Gully erosion: Impacts, factors and control. Catena, v. 63, n. 2-3, p. 132-153, 2005.

WEHR, A. \& LOHR, U. Airborne laser scanning - an introduction and overview. ISPRS Journal of Photogrammetry \& Remote Sensing, v. 54, p. 68-82, 1999

XIMENES NETO, A.R.; MOURA, F.M.; BRINDEIRO, O.S.; SILVA, R.R.; MACIEL, F.J.M.; MORAIS, J.O. Caracterização Das Paleofalésias Na Planície Costeira Do Ceará, Nordeste Do Brasil. 543 p IN: Roque et al., - Rio de Janeiro: FGEL -UERJ. Saindo Da Zona De Conforto: A Interdisciplinaridade Das Zonas Costeiras / Tomo VIII da Rede BRASPOR. Capitulo 14, 2019.

Submetido em 28 de novembro de 2019 Aceito para publicação em 22 de maio de 2020 